\title{
Corona Buat Ekonomi Merana
}

\author{
Chania Dufan \\ 191011650053
}

\section{Chaniadufan01@gmail.com}

Pada awal tahun 2020 muncul virus yang menggemparkan dunia, virus ini menjadi wabah yang mematikan juataan umat manusia. Virus corona atau covid-19. Sebenarnya virus ini ditemukan pada akhir tahun 2019 yaitu pada bulan 31 Desember, di Wuhan China. Virus ini menyebar ke seluruh dunia termasuk Indonesia. Virus ini dapat menular dengan sangat mudah bisa lewat udara, cairan didalam mulut atau lendir yang berasal dari hidung. Penyebaran virus ini membuat panik seluruh warga dunia. Dengan penyebaran yang sangat cepat ini, hampir semua pemerintah dunia memberlakukan lockdown, dengan 
pemberlakukan lockdown pemerintah berharap hal tersebut dapat mencegah penyebaran virus covid-19.

Pemberlakuan lockdown tentu saja membuat measyarakat tidak bisa berkutik sedikitpun. Bahkan untuk konsumsi saja mereka harus menggunakan jasa antar. Seluruh kegiatan lumpuh tidak terkecuali kegiatan sektor perekonomian. Kegiatan perekonomian seluruh dunia turun drastis.Tidak sedikit perusahaan gulung tukar akibat wabah yang menyebar ini. Selain perusahaan besar hal ini juga berdampak pada pedagang kecil. Selama lockdown di berlakukan mereka tidak lagi bisa bebas berjualan keliling ataupun berjualan ditempat.

Dampak virus ini sangat besar di bidang ekonomi, mulai dari banyaknya karyawan yang di PHK dan para pedangang yang kehabisan modal karena terlalu lama tidak berjualan. Hal itu tentu saja akan membuat angka pengangguran di indonesia 
semakin meningkat, dan membuat indeks kemiskinan di negara ini semakin melambung tinggi. Kemiskinan yang melanda masyarakat menegah bawah membuat mereka depresi. Menurut Kurniawan (2019) fenomena kemiskinan bukanlah disebabkan oleh hal yang alamiah atau semata mata karena kemalasan, namun karena ada struktur yang menyebabkan hal tersebut terjadi. Jadi kemiskinan tidak hanya disebabkan oleh kemalasan seseorang namun banyak faktor yang mempengaruhi terjadinya kemiskinan. 


\section{Referance}

Kurniawan, W. (2019). Islam dan Permasalahan

Kesejahteraan Ekonomi. Jurnal Ilmiah

Humanika, 2(2), 11-22.

Kurniawan, W. (2020). Lanskap Keagamaan

Indonesia. Pena Persada: Purwokerto

Kurniawan, W. (2020). Agama, Pendidikan dan Kita.

El-Markazi: Bengkulu 